\title{
PERBANDINGAN PENGUKURAN STATUS SEDASI RICHMON AGITATION SEDATION SCALE (RASS) DAN RAMSAY SEDATION SCALE (RSS) PADA PASIEN GAGAL NAFAS TERHADAP LAMA WEANING VENTILATOR DI GICU RSUP Dr. HASAN SADIKIN BANDUNG
}

\author{
Hellena Deli* ; Muhammad Zafrullah Arifin ; Sari Fatimah \\ Magister Keperawatan Konsentrasi Keperawatan Kritis ; Universitas Padjadjaran Bandung \\ Jl.Raya Bandung-Sumedang Km. 21 ; Jatinangor ; Sumedang
}

\begin{abstract}
Abstrak
Untuk mencegah pemberian sedasi yang berlebih dibutuhkan satu alat ukur yang yang mampu mengukur status sedasi pasien dengan akurat. Penelitian ini bertujuan untuk menganalisis perbedaan pengukuran status sedasi Richmond Agitation Sedation Scale (RASS) dan Ramsay Sedation Scale (RSS) pada pasien gagal nafas terhadap lama weaning ventilator. Penelitian ini merupakan penelitian observasional analitik dengan pendekatan kohort prospektif yang terdiri dari satu kelompok dependen dengan jumlah responden 13 orang. Pengukuran status sedasi dilakukan dengan dua alat ukur yaitu RASS dan RSS kemudian akan diamati hingga pasien berhasil weaning ventilator ke modus CPAP atau PS CPAP dengan PS 5-8 CmH2O dan PEEP $5 \mathrm{cmH}_{2} \mathrm{O}$. Hasil penelitian ini menunjukkan pengukuran status sedasi dengan RASS dan RSS memiliki pengaruh yang signifikan terhadap lama weaning ventilator dengan nilai $\mathrm{p}<0,05$. Berdasarkan hasil analisis terdapat perbedaan yang bermakna antar pengukuran status sedasi yang diukur dengan RASS dan RSS pada pasien gagal nafas terhadap lama weaning ventilator dengan nilai $\mathrm{p}<0,05$, dan hasil post hoc analisis menunjukkan terdapat perbedaan pada setiap pengukuran sedasi dengan nilai $\mathrm{p}<0,05$. Pengukuran status sedasi dengan RASS lebih baik dalam mengurangi lama weaning ventilator dibandingkan dengan RSS.
\end{abstract}

Kata kunci: Gagal nafas ; lama weaning ; RASS ; RSS

\begin{abstract}
[COMPARATIVE MEASUREMENT STATUS SEDASI RICHMON AGITATION SEDATION SCALE (RASS) AND RAMSAY SEDATION SCALE (RSS) IN RESPIRATORY FAILURE PATIENT AGAINST TIME WEANING VENTILATOR IN GICU Dr. HASAN SADIKIN BANDUNG] To prevent over sedation need an instrument can measure accurately the status of sedation. This study aimed to analyze the differences between Richmond Agitation Sedation Scale (RASS) and the Ramsay Sedation Scale (RSS) in measuring the status of sedation for respiratory failure patient against time weaning ventilator. This study is observational analytic with prospective cohort study. This study was conducted in 13 respiratory failure patient and use mechanical ventilator. Sampling is done by non probability sampling method with consecutive sampling that received sedation therapy in GICU RSUP Dr Hasan Sadikin, Bandung. Samples will be measured with two sedation instrument they are RASS and RSS. Patient will be observed until the patient is successfully weaning ventilator mode CPAP or CPAP PS with PS 5-8 cmH2O and PEEP $5 \mathrm{cmH} 2 \mathrm{O}$. These results indicate the measurement status with RASS sedation and RSS have a significant impact on weaning ventilator time with a value of $p<0,05$. Based on analysis results there is a significant difference between the measurement of sedation status by RASS and RSS for respiratory failure patient and weaning ventilator time with $p<0,05$, and the post hoc analysis shows that there are differences in each measurement sedation with $p<0,05$. Measurement status with RASS sedation better in reducing the length of ventilator weaning compared to RSS.
\end{abstract}

Keywords: Respiratory failure ; Duration of weaning ; RASS ; RSS

\footnotetext{
*) Hellena Deli

E-mail: hellenadeli.hd@gmail.com
} 


\section{Pendahuluan}

Kegagalan pernapasan merupakan salah satu indikasi pasien dirawat di ruangan intensive care unit (ICU). Kegagalan pernapasan merupakan salah satu penyebab meningkatnya mortalitas dan morbiditas. Setiap tahunnya diperkirakan 1 juta orang dirawat di ICU karena gagal nafas (Wunsch, et al, 2010). Di Amerika Serikat kejadian gagal nafas meningkat dari 1.007.549 orang pada tahun 2001 menjadi 1.917.910 pada tahun 2009 (Stefan, et al, 2013). Penelitian yang dilakukan oleh Franca et al (2011) pada 12 ruangan ICU yang ada di Brazil didapatkan 843 orang $(49 \%)$ di rawat di ruangan ICU karena gagal nafas akut dan 141 orang menderita gagal nafas setelah dirawat di ICU, dari total penderita gagal nafas akut tersebut sebanyak 475 orang meninggal di ruangan ICU dan 56 orang meninggal setelah keluar dari ICU. Dibutuhkan suatu penanganan khusus untuk mengatasi kegagalan pernapasan. Salah satu penatalaksanaan untuk mengatasi gagal nafas adalah pemberian bantuan pernafasan melalui ventilator yang berfungsi untuk membantu fungsi paru dalam pemenuhan oksigen tubuh.

Tindakan pemasangan alat bantu pernafasan dapat menimbulkan ketidaknyamanan dan nyeri bagi pasien, yang tidak jarang mengakibatkan terjadinya agitasi pada pasien. Selain itu agitasi dapat terjadi akibat ketidaknyamanan terhadap lingkungan dan suara bising yang ditimbulkan oleh alat-alat. Agitasi merupakan suatu keadaan dimana pasien terlihat gelisah, ketidaknyamanan ditandai oleh gerakan motorik yang tidak terkendali yang dapat mengakibatkan cedera dan ekstubasi (Brandl et al, 2001; Sessler et al, 2002). Penatalaksanaan farmakologis yang dilakukan untuk mengatasi agitasi pada pasien gagal nafas adalah dengan menggunakan obat-obatan sedasi dan analgetik.

Pemberian obat sedasi pada pasien gagal nafas bertujuan untuk menginduksi anxiolysis, mencegah terjadinya agitasi, memfasilitasi manipulasi ventilator dan mencegah terjadinya asynchrony ventilator (Ennis \& Brophy, 2011). Pemberian sedasi yang berlebihan berbahaya dan memiliki efek samping diantaranya dapat mengakibatkan penekanan sistem pernapasan, bradikardi, hipotensi, ketergantungan penggunaan ventilator, mengaburkan pemeriksaan neurologis, meningkatkan lama hari rawat, penggunaan sedasi berkepanjangan dapat mengganggu pola tidur, mengakibatkan kelelahan, yang mengarah kepada penggunaan sedasi yang berlebihan (Sessler et al, 2002; Triltsch et al, 2005; Girard et al, 2008). Sedasi memiliki efek terhadap pusat napas, relaksasi terhadap jalan nafas, hipoperfusi batang otak dan peningkatan retensi jalan nafas. Penggunaan sedasi yang berlebihan dapat mengakibatkan pengembalian fungsi paru menjadi lebih lambat, sehingga weaning ventilator menjadi lebih lambat (Conti, Mantz, Longrois, \& Tonner, 2014). Pasien dengan status sedasi dalam, pada 48 jam pertama perawatan dapat meningkatkan lama waktu ektubasi dan mortalitas pasien (Shehabi et al, 2012).

Keputusan untuk mengatasi agitasi pada pasien dengan memberikan obat sedasi membutuhkan pengukuran yang konsisten, pemberian obat sedasi dengan dosis yang tidak pantas dapat membahayakan pasien (Triltsch et al, 2005; Grap et al, 2012). Keselamatan pasien dalam penggunaan obat-obatan sedasi merupakan hal penting dan telah dijadikan standar oleh joint commicion acreditation (The Joint commicion, 2012). Pemahaman tentang obat yang umum digunakan adalah penting untuk merumuskan rencana sedasi untuk setiap pasien, dengan penggunaan sedasi dan analgetik yang tepat dapat meningkatkan kualitas pelayanan dan dapat mengurangi lama penggunaan ventilator (Brattebo et al, 2002).

Keputusan untuk memberikan obat sedasi merupakan wewenang dokter dan perawat memiliki peran untuk mengelolanya dengan tepat. Penggunaan sedasi untuk mengatasi nyeri dan agitasi tidak hanya membutuhkan hubungan yang baik antara perawat dan dokter, namun penilaian sedasi agitasi pasien juga membutuhkan penilaian independen dari perawat. Perawat memiliki peranan penting dalam penilaian sedasi secara terus menerus.

Disamping itu perawat memiliki peran sebagai advokat untuk memastikan bahwa pasien dan keluarga telah diinformasikan dan dididik mengenai resiko yang mungkin muncul akibat penggunaan analgetik dan sedasi dan memastikan bahwa terapi yang diberikan dokter sesuai dengan kondisi yang dialami oleh pasien (Walker \&, Gillen, 2006). Perawat dituntut untuk mampu melaporkan status sedasi pasien dengan tepat, sehingga perawat perlu memiliki pemahaman yang baik mengenai manajemen, pengelolaan analgetik dan sedasi, dan penilaian status sedasi pasien yang dapat mempengaruhi pengambilan keputusan terkait pemberian analgetik dan sedasi (Randen \& Bjork, 2010). Perawat juga harus mampu berkolaborasi dengan dokter dalam penilaian status sedasi pasien untuk pengambilan keputusan yang tepat (Taylor, 2006). 
Kriteria waktu dalam weaning ventilator merupakan hal yang sangat penting, semakin cepat pelaksanaan weaning ventilator semakin baik, namun bila proses weaning ventilator terlalu cepat dilakukan maka akan mengakibatkan proses adaptasi terhadap fungsi pernapasan juga semakin cepat, sehingga sering menimbulkan intubasi ulang (Boles et al, 2007). Weaning ventilator mampu melatih kemampuan pasien untuk beradaptasi dan mampu mengembalikan fungsi fisiologis pernafasan pasien. Pengukuran status sedasi merupakan suatu keterampilan klinis yang juga harus dimiliki oleh perawat. Penilaian terstruktur sedasi dan agitasi berguna untuk titrasi obat penenang, untuk mengevaluasi perilaku gelisah dan kedalaman status sedasi pasien (Sesler, et al, 2002). Ketepatan dalam penilaian kondisi pasien dapat mengurangi kemungkinan yang dapat membahayakan pasien. Sehingga dibutuhkan alat ukur yang akurat untuk mampu mengukur status sedasi pasien terpasang ventilator.

Pengukuran status agitasi harus dilakukan secara subjektif dan objektif. Penilaian ini dibutuhkan untuk mencegah terjadinya perbedaan persepsi diantara petugas kesehatan. Penilaian subjektif dilakukan dengan observasi aktivitas fisik pasien, ekspresi wajah dan respon fisiologis yang muncul. Observasi yang dilakukan untuk menilai agitasi dapat menimbulkan perbedaan persepsi antara tim kesehatan (Hernandez-Gancedo et al, 2006), dengan tidak adanya standarisasi yang diterapkan dalam pengukuran mengakibatkan pemberian obat sedasi dan analgetik berdasarkan pengalaman klinis dokter tanpa pengawasan yang ketat mengenai intensitas pemberian sedasi (Sessler et al, 2002; Ely et al, 2003; Triltsch et al, 2005).

Untuk mencegah munculnya variasi dibutuhkan alat ukur yang dapat mengukur status sedasi pasien. Menurut American Society of Anesthesiologists (2002) terdapat empat level sedasi yaitu anxiolysis, tersedasi sadar, sedasi dalam dan anastesi umum. Rassin et al (2007), melakukan uji interrater reliability terhadap tiga alat ukur yaitu Richmond Agitation Sedation Scale (RASS), Sedation Agitation Scale (SAS), dan Visual Analog Scale (VAS), didapatkan hasil bahwa RASS merupakan alat ukur yang valid dan reliable untuk mengukur status sedasi pasien di ICU ( $r=$ 0,91). Hal ini dikarenakan RASS lebih spesifik dari pada VAS dan SAS, sehingga mempersempit penilaian subjektif yang dihasilkan tim penilai. RASS mampu memisahkan antara respon verbal dan fisik, selain itu RASS mampu mengukur periode waktu dimana pasien memiliki kontak mata dalam menanggapi rangsangan verbal, sehingga meningkatkan sensitivitas. Menurut Sessler et al (2002) RASS memiliki 4 poin nilai untuk menilai status agitasi dan 5 poin untuk menilai status sedasi, dan nilai 0 menunjukkan pasien tidak tersedasi.

Ramsay sedation scale (RSS) merupakan alat ukur sedasi yang banyak digunakan saat ini. RSS terdiri dari dua kelompok yaitu untuk penilaian level 1,2,3 merupakan penilaian untuk kondisi pasien terjaga, dan level 4,5,6 merupakan penilaian pada pasien tersedasi. Tingkatan dari skala RSS memungkinkan penilaian visual agitasi sedasi pada pasien yang responsif terhadap penilaian tersebut. Skala ini dapat digunakan oleh dokter dan perawat untuk menilai status sedasi pasien, digunakan sebagai alat untuk membimbing mereka untuk memastikan kebutuhan perubahan dosis serta obat-obatan sedasi yang digunakan, namun RSS tidak mampu menentukan tingkat kedalaman sedasi pasien (Dawnson, Fintel, \& Nairn, 2010).

Penelitian ini bertujuan untuk mengetahui perbedaan status sedasi yang diukur dengan Richmond Agitation Sedation Scale (RASS) dan Ramsay Sedation Scale (RSS) pada pasien gagal nafas terhadap lama weaning ventilator $\mathrm{di}$ general intensive care unit (GICU) RSUP Dr Hasan Sadikin Bandung.

\section{Metode}

Penelitian ini merupakan penelitian observasional analitik dengan pendekatan cohort study prospektif, peneliti akan menguji perbandingan dua instrumen penilaian status sedasi pada pasien gagal nafas terhadap lama weaning ventilator, dimana peneliti akan memulai penelitian dengan meneliti variabel independen pada sampel. Penilaian terhadap status sedasi pasien dilakukan pada hari pertama pasien masuk dan atau hari pertama pasien terpasang ventilator dan mendapat terapi sedasi, kemudian pasien akan diikuti hingga modus ventilator CPAP atau PS CPAP dengan PEEP $5 \mathrm{cmH} 2 \mathrm{O}$ dan PS 5-8 cmH2O. Penelitian ini menggunakan pendekatan tekhnik matching berdasarkan jenis sedasi yang digunakan yaitu midazolam.

Subjek penelitian ini adalah pasien yang dirawat di GICU RSUP dr Hasan Sadikin Bandung pada bulan Maret hingga Mei 2015 yang memenuhi kriteria penelitian. Kriteria inklusi pada penelitian ini adalah pasien gagal nafas dengan rentang usia 15 - 65 tahun, GCS $\geq$ 8 , terpasang ventilator dan mendapat terapi 
midazolam. Kriteria ekslusi adalah pasien dengan pemasangan ventilator $<48$ jam, pasien yang mendapat obat relaksasi otot, pasien dengan gangguan pada cervical 1- 3, pasien dengan gangguan pada sistem saraf pusat, pasien dengan riwayat gangguan penglihatan dan pendengaran, pasien dengan gangguan otot pernapasan. Kriteria drop out pada penelitian ini adalah pasien yang meninggal sebelum weaning ventilator.

\section{Hasil dan Pembahasan}

Penelitian ini dilakukan pada 13 orang pasien yang dirawat di GICU RSUP Dr Hasan Sadikin Bandung yang terpasang ventilator mekanik dan mendapat terapi sedasi yang telah memenuhi kriteria inklusi. Karakteristik responden pada penelitian ini mayoritas usia responden berada pada rentang 21-40 tahun dan 41-60 tahun masing-masing sebanyak 5 responden, dengan diagnosis medis pasien masuk ke ruangan GICU adalah pasien post operasi sebanyak 12 orang (92,3\%). Sebagian besar responden mendapatkan dosis sedasi $3 \mathrm{mg}$ sebanyak 6 orang (46,2\%). Mayoritas kadar $\mathrm{Hb}$ responden $\geq 9,5 \mathrm{~g} / \mathrm{dl}$ sebanyak 7 orang $(53,8 \%)$ dan kadar albumin $\geq 2,6 \mathrm{~g} / \mathrm{dl}$ sebanyak 9 orang $(60,9 \%)$. Berdasarkan status sedasi, mayoritas skor RASS awal -3 sebanyak 6 orang $(46,2 \%)$, skor akhir RASS 0 sebanyak 8 orang $(61,5 \%)$, skor awal RSS 4 sebanyak 6 orang $(46,2 \%)$, dan seluruh responden memiliki skor akhir RSS 2. Seluruh responden yang diukur memiliki karakteristik yang homogen atau tidak berbeda secara signifikan dengan $P$ value $>$ 0,05 (Tabel 1).

Tabel 1. Uji homogenitas karakteristik responden

\begin{tabular}{lccc}
\hline \multicolumn{1}{c}{ Karakteristik } & $\mathrm{F}$ & $\%$ & P value \\
\hline Usia & & & \\
$\quad 13-20$ tahun & 1 & $7,7 \%$ & \\
$21-40$ tahun & 5 & $38,46 \%$ & $0,705^{\mathrm{a}}$ \\
$\quad 41-60$ tahun & 5 & $38,46 \%$ & \\
$\quad>60$ tahun & 2 & $15,38 \%$ & \\
\hline Diagnosa Medis & & & \\
Bedah & 12 & $92,3 \%$ & $1,000^{\mathrm{b}}$ \\
Non Bedah & 1 & $7,7 \%$ & \\
\hline Dosis Sedasi & & & \\
2 mg & 1 & $7,7 \%$ & \\
$\quad 3$ mg & 6 & $46,2 \%$ & $0,485^{\mathrm{a}}$ \\
5 mg & 5 & $38,5 \%$ & \\
$10 \mathrm{mg}$ & 1 & $7,7 \%$ & \\
\hline Kadar HB & & & \\
$\quad<9,5$ & 6 & $46,2 \%$ & $0,409^{\mathrm{a}}$ \\
$\quad \geq 9,5$ & 7 & $53,8 \%$ & \\
\hline Albumin & & & \\
$\quad<2,6$ & 4 & $30,8 \%$ & $0,181^{\mathrm{a}}$ \\
$\quad \geq 2,6$ & 9 & $60,9 \%$ & \\
\hline Skor RASS Awal & & & \\
$\quad-4$ & 2 & $15,4 \%$ & $0,879^{\mathrm{a}}$ \\
\hline-3 & 6 & $46,2 \%$ & \\
\hline
\end{tabular}

\begin{tabular}{cccc}
\hline-2 & 4 & $30,8 \%$ & \\
-1 & 1 & $7,7 \%$ & \\
\hline Skor RASS Akhir & & & \\
-1 & 5 & $38,5 \%$ & $0,447^{\text {a }}$ \\
0 & 8 & $61,5 \%$ &
\end{tabular}

\begin{tabular}{|c|c|c|c|}
\hline \multicolumn{4}{|l|}{ Skor RSS Awal } \\
\hline 2 & 1 & $7,7 \%$ & \\
\hline 3 & 4 & $30,8 \%$ & $0,879^{\mathrm{a}}$ \\
\hline 4 & 6 & $46,2 \%$ & \\
\hline 5 & 2 & $15,4 \%$ & \\
\hline Skor RSS Akhir & & & \\
\hline 2 & 13 & $100 \%$ & $1,000^{a}$ \\
\hline
\end{tabular}

Analisis statistik yang digunakan untuk melihat perbedaan rerata skor status sedasi yang diukur dengan RASS dan RSS pada pasien gagal nafas terhadap lama weaning ventilator adalah dengan uji wilcoxon dikarenakan data tidak berdistribusi normal. Hasil penelitian ini menunjukkan terdapat perbedaan rerata skor pengukuran sedasi dengan menggunakan RASS pada awal dan akhir dengan nilai significancy 0,001 dan terdapat perbedaan pengukuran sedasi awal dan akhir yang diukur dengan menggunakan RSS terhadap lama weaning ventilator dengan nilai significancy $0,002(\mathrm{p}<0,05)$ dengan alfa 5\% (tabel 2). Berdasarkan hasil tersebut dapat diputuskan bahwa secara statistik terdapat perbedaan yang bermakna pengukuran status sedasi awal dan akhir yang diukur dengan RASS pada pasien gagal nafas terhadap lama weaning ventilator.

Tabel 2. Perbedaan rerata skor status sedasi yang diukur dengan RASS dan RSS pada pasien gagal nafas terhadap lama weaning ventilator.

\begin{tabular}{lccc}
\hline \multicolumn{1}{c}{ Variabel } & $\mathrm{N}$ & $\begin{array}{c}\text { Median } \\
\text { (minimum- } \\
\text { maksimum) }\end{array}$ & $\mathrm{P}$ \\
\hline $\begin{array}{l}\text { Skor awal } \\
\text { RASS }\end{array}$ & 13 & $-3(-4--1)$ & 0,001 \\
$\begin{array}{l}\text { Skor akhir } \\
\text { RASS }\end{array}$ & 13 & $0(0--1)$ & \\
\hline $\begin{array}{l}\text { Skor awal RSS } \\
\text { Skor akhir }\end{array}$ & 13 & $4(2-5)$ & 0,002 \\
RSS & 13 & $2(2-3)$ & \\
\hline
\end{tabular}

Analisis perbandingan pengukuran status sedasi Richmond Agitation Sedation Scale dan Ramsay Sedation Scale pada pasien gagal nafas terhadap lama weaning ventilator dengan menggunakan uji Friedman. Uji ini dilakukan 
untuk menjawab hipotesis penelitian. Berdasarkan tabel 3 didapatkan nilai $p<0,001(p$ lebih kecil dari 0,05) dengan alfa 5\% dan dapat disimpulkan bahwa terdapat perbedaan nilai pengukuran status sedasi, sehingga hipotesis penelitian diterima dan dapat disimpulkan bahwa pengukuran tingkat sedasi dengan menggunakan RASS lebih baik dalam mengurangi lama weaning ventilator dibandingkan RSS. Untuk melihat perbedaan pada masing-masing penilaian maka dilakukan uji post hoc dengan uji wilcoxon dan didapatkan bahwa terdapat perbedaan pada setiap pengukuran status sedasi antara skor awal RASS, skor akhir RASS, skor awal RSS dan skor akhir RSS dengan nilai signifikansi pada setiap pengukuran < 0,05, dengan demikian dapat disimpulkan bahwa terdapat perbedaan pada setiap pengukuran status sedasi.

Tabel 3. Perbandingan pengukuran status sedasi dengan RASS dan RSS pada pasien gagal nafas terhadap lama weaning ventilator.

\begin{tabular}{lccc}
\hline \multicolumn{1}{c}{ Variabel } & $\mathrm{N}$ & $\begin{array}{c}\text { Median (minimum- } \\
\text { maksimum) }\end{array}$ & $\mathrm{P}$ \\
\hline $\begin{array}{l}\text { Skor awal } \\
\text { RASS }\end{array}$ & 13 & $-3(-4--1)$ \\
$\begin{array}{l}\text { Skor akhir } \\
\text { RASS }\end{array}$ & 13 & $0(0--1)$ & $<0,001$ \\
$\begin{array}{l}\text { Skor awal RSS } \\
\text { Skor akhir RSS }\end{array}$ & 13 & $4(2-5)$ & \\
& & $2(2-3)$ & \\
\hline
\end{tabular}

Pemantauan status sedasi pada pasien yang terpasang ventilator merupakan suatu komponen penting untuk meningkatkan pelayanan di rumah sakit. Pemberian sedasi sangat berpengaruh terhadap keberhasilan weaning ventilator dan telah dibuktikan oleh beberapa penelitian. Berdasarkan tabel 2 menunjukkan bahwa pengukuran status sedasi pada awal dan akhir penggunaan sedasi dengan menggunakan RASS sebagai salah satu alat ukur untuk menilai status sedasi memiliki perbedaan yang signifikan terhadap lama weaning dengan nilai $P=0,001$ dibandingkan penilaian status sedasi dengan menggunakan RSS $(P=0,002)$ dengan alfa $5 \%$. Hal ini menunjukkan bahwa penggunaan skala ukur RASS dalam mengukur status sedasi memiliki perbedaan yang lebih signifikan terhadap lama weaning ventilator dibandingkan RSS.

Pada tabel 3 menunjukkan hasil analisis bivariat dengan uji Friedman didapatkan perbandingan pengukuran status sedasi dengan menggunakan RASS dan RSS terhadap lama weaning ventilator memiliki perbedaan yang bermakna dengan nilai $\mathrm{p}<0,001$. Hasil penelitian ini menunjukkan bahwa hipotesis penelitian diterima yaitu pengukuran status sedasi menggunakan RASS lebih baik dalam mengurangi lama weaning ventilator dibandingkan dengan RSS.

Hasil uji post hoc terhadap kedua alat ukur ini menunjukkan terdapat perbedaan pada setiap pengukuran dengan kedua alat ukur dengan nilai signifcancy $p<0,05$. Hal ini menunjukkan bahwa penggunaan RASS sebagai salah satu alat ukur yang digunakan untuk memantau status sedasi lebih baik dalam mengurangi lama weaning ventilator dibandingkan RSS. Hasil penelitian ini mendukung penelitian yang dilakukan oleh Ely et al (2003) dan Mendes et al (2008). Penelitian yang dilakukan oleh Ely et al (2003) terhadap pasien yang terventilator didapatkan pasien dengan status sedasi -3 hingga 0 berada pada status sedasi sedang hingga minimal sehingga pada skor ini pasien dapat dilakukan weaning ventilator dan ekstubasi. Tindakan weaning ventilator dan ekstubasi pada pengukuran status sedasi dengan menggunakan RSS dapat dilakukan pada skor 2, yang menunjukkan pasien berada pada dosis tersedasi minimal ataupun tidak tersedasi (Girard et al, 2008).

Menurut Ely et al (2003) pengukuran status sedasi dengan RASS mampu memisahkan respon verbal dan stimulasi fisik sehingga status agitasi dan sedasi dapat dipisahkan berdasarkan potensi dari stimulus yang diberikan. Berdasarkan penelitian yang dilakukan oleh Mendes et al (2008) terdapat korelasi yang bermakna antara skor RASS dan RSS. RASS memungkinkan penilaian yang lebih spesifik dikarenakan memiliki tingkatan yang jelas. Level sedasi yang adekuat pada RSS berada pada skor 2 hingga 4, sedangkan pada RASS berada pada skor 0 hingga -3 . Level sedasi yang adekuat memiliki korelasi positif dengan probabilitas kehidupan. Skor sedasi RSS $\geq 5$ dan RASS $\geq 4$ memiliki korelasi yang positif terhadap kematian dengan nilai AUC > 0,78.

Menurut Ismaeil et al (2014), kejadian gagal ekstubasi pada pasien yang tersedasi terjadi pada pasien dengan skor $>2$. Hal ini terjadi sebagai akibat dari belum berfungsinya sistem pernapasan dengan baik sebagai akibat dari pemberian sedasi. Menurut Jakob et al (2007), status sedasi sangat berpengaruh terhadap lama penggunaan ventilator, kejadian VAP dan dapat meningkatkan lama hari rawat. 
RSS memiliki kekurangan yaitu kurangnya level pengukuran agitasi yang berpengaruh terhadap penentuan pemberian dosis sedasi, selain itu level status sedasi pada RSS tidak memiliki level yang jelas terhadap status sedasi, sehingga status sedasi pasien tidak dapat terpantau dengan baik (Ramsay et al, 2002; Walsh, Ramsay, \& Kinnunen, 2008). RASS mampu mengukur kualitas serta tingkat sedasi dikarenakan RASS memiliki nilai psikometrik interrater reliability dan validity yang paling tinggi dibandingkan skala sedasi yang lain serta mampu membedakan tingkatan sedasi pada berbagai kondisi klinis (Barr et al, 2013). RASS memiliki tingkatan khusus dalam mengukur status sedasi, sehingga dapat dijadikan dasar untuk titrasi sedasi (Seidabady, et al, 2014). RASS memiliki penilaian yang lebih spesifik terhadap status sedasi sehingga dapat mempersempit penilaian subjektif yang dihasilkan oleh tim penilai (Rassin et al, 2007).

Menurut Seidabady et al (2014), RSS lebih sering digunakan karena memiliki 6 tingkatan untuk mengukur status agitasi sedasi. Namun RSS memiliki kelemahan karena tidak mampu mengukur level atau kedalaman sedasi, sehingga tidak dapat dijadikan dasar yang pasti untuk melakukan titrasi sedasi. Hal ini berarti penilaian RSS lebih subjektif dibandingkan RASS, sehingga RASS lebih baik digunakan untuk menilai status sedasi pada pasien yang terpasang ventilator.

RASS dirancang dengan cara memiliki definisi yang tepat dan jelas untuk status sedasi dan tergantung kepada evaluasi kesadaran dengan menilai reaksi sederhana yang muncul meliputi respon membuka mata, kontak mata dan gerakan fisik, sedangkan pengukuran status sedasi dengan menggunakan RSS tidak menunjukkan respon yang cukup jelas terhadap penilaian yang dilakukan (Tadrisi et al, 2009). RASS menunjukkan nilai validitas dan reliabilitas yang tinggi dalam mengukur status sedasi pada pasien yang mendapat terapi sedasi continuous yang telah diuji pada beberapa kelompok pasien ICU yang terpasang ventilator mekanik (Sessler et al, 2008).

Penelitian yang dilakukan oleh Prottengeier, Moritz, Heinrich, Gall, \& Schmidt (2014), pada pasien yang mendapat terapi sedasi didapatkan skor RASS memiliki korelasi yang sangat baik terhadap bispectral indeks (BIS) EEG dengan nilai sensitifitas 0,97 (CI 0,89-1,00) dan nilai positive predictive value 0,59 (CI 0,45-0,71). Sedangkan penelitian yang dilakukan oleh Consales, Chelazzi, Rinaldi, \& De Gaudio (2006) pada pasien yang mendapat terapi sedasi didapatkan bahwa skor
RSS memiliki korelasi yang baik dengan BIS EEG dengan nilai sensitifitas 0,75. Hal ini menunjukkan bahwa RASS memiliki korelasi yang lebih baik terhadap penilaian BIS EEG dibandingkan RSS. Adanya korelasi yang sangat baik antara RASS dan BIS menunjukkan bahwa RASS dapat dijadikan salah satu alat ukur yang paling tepat dan akurat untuk mengukur status sedasi pasien gagal nafas yang terpasang ventilator.

RASS memiliki korelasi yang sangat baik dengan nilai Glasgow Comma Scale (GCS) dengan nilai r 0,91, nilai GCS $<9$ berkorelasi dengan skor RASS -3 sampai dengan -5 dan nilai GCS $\geq$ 9 berkorelasi dengan skor RASS -2 sampai dengan 0 (Ely et al, 2003; Rassin el al, 2007). Sehingga penggunaan RASS sebagai salah satu alat ukur status sedasi dapat dijadikan suatu indikator status kesadaran pasien. Evaluasi yang sistematis dari status sedasi dan analgetik merupakan dasar dari pengobatan dan perawatan pada pasien kritis (Martin et al, 2010; Lutz \& Spies, 2011). Pemantauan status sedasi dengan menggunakan RASS dapat mengurangi lama penggunaan ventilator dan lama hari rawat di ICU (Martin et al, 2010). Pengkajian status sedasi pada pasien yang terpasang ventilator merupakan salah satu komponen penting, selain itu pengukuran status sedasi memiliki peranan yang sangat penting dalam komunikasi antara tim kesehatan yang berada di ICU. Hal ini penting untuk mencegah penggunaan sedasi yang berlebih, serta meminimalisir ketidaknyamanan dan nyeri, selain itu pengkajian status sedasi juga dijadikan sebagai salah satu indikator weaning ventilator (Conti et al, 2014).

\section{Simpulan dan Saran}

Pengukuran status sedasi dengan RASS lebih baik dalam mengurangi lama weaning ventilator dibandingkan dengan RSS.

\section{Ucapan Terimakasih}

Ucapan terimakasih disampaikan kepada Direktur Poltekkes Kemenkes Semarang, Ketua Jurusan, Ketua Prodi, keluarga, mitra sejawat, responden, dan semua pihak yang terlibat dalam penelitian ini. 


\section{Daftar Pustaka}

7. American Association of Nurse Anaesthetists. (2008). Scope and standards for nurse anesthesia practice.

Barr, J., Fraser, G. L., Puntillo, K., Ely, E. W., Gélinas, C., Dasta, J. F., ... \& Jaeschke, R. (2013). Clinical practice guidelines for the management of pain, agitation, and delirium in adult patients in the intensive care unit: Executive summary. Am J Health Syst Pharm, 70(1), 53-58.

Boles, J. M., Bion, J., Connors, A., Herridge, M., Marsh, B., Melot, C., ... \& Welte, T. (2007). Weaning from mechanical ventilation. European Respiratory Journal, 29(5), 1033-1056.

Brandl, K. M., Langley, K. A., Riker, R., Dork, L. A., Qualls, C. R., \& Levy, H. (2001). Confirming the Reliability of the Sedation-Agitation Scale Administered by ICU Nurses without Experience in Its Use. Pharmacotherapy: The Journal of Human Pharmacology and Drug Therapy, 21(4), 431-436.

Brattebo, G., Hofoss, D., Flaatten, H., Muri, A. K., Gjerde, S., \& Plsek, P. E. (2002). Quality improvement report: Effect of a scoring system and protocol for sedation on duration of patients' need for ventilator support in a surgical intensive care unit. BMJ: British Medical Journal, 324(7350), 1386.

Consales, G., Chelazzi, C., Rinaldi, S., \& De Gaudio, A. R. (2006). Bispectral Index compared to Ramsay score for sedation monitoring in intensive care units. Minerva anestesiologica, 72(5), 329-336.

Conti, G., Mantz, J., Longrois, D., \& Tonner, P. (2014). Sedation and weaning from mechanical ventilation: time for 'best practice'to catch up with new realities?. Multidisciplinary respiratory medicine, 9(1), 45.

Dawson, R., Fintel, N. V., \& Nairn, S. (2010). Sedation assessment using the Ramsay scale: Rachel Dawson and colleagues review the reliability of tools for assessing sedation and how these differ from methods of measuring consciousness. Emergency Nurse, 18(3), 18-20.

Ely, W. E., Truman, B., Shintani, A., Thomason, J. W., Wheeler, A. P., Gordon, S., et al. (2003). Monitoring Sedation Status Over Time in ICU Patients. Intensive Care medicine, 289(22). doi:10.1001/jama.289.22.2983.

Ennis, K. M., \& Brophy, G. M. (2011). Management of Intracranial Hypertension: Focus on Pharmacologic Strategies. AACN advanced critical care, 22(3), 177-182.
Franca, S. A., Toufen Junior, C., Hovnanian, A. L. D., Albuquerque, A. L. P., Borges, E. R., Pizzo, V. R., \& Carvalho, C. R. R. (2011). The epidemiology of acute respiratory failure in hospitalized patients: a Brazilian prospective cohort study. Journal of critical care, 26(3), 330-e1.

Girard, T. D., Kress, J. P., Fuchs, B. D., Thomason, J. W., Schweickert, W. D., Pun, B. T., ... \& Ely, E. (2008). Efficacy and safety of a paired sedation and ventilator weaning protocol for mechanically ventilated patients in intensive care (Awakening and Breathing Controlled trial): a randomised controlled trial.The Lancet, 371(9607).

Grap, M. J., Munro, C. L., Wetzel, P. A., Best, A. M., Ketchum, J. M., Hamilton, V. A., ... \& Sessler, C. N. (2012). Sedation in adults receiving mechanical ventilation: Physiological and comfort outcomes. American Journal of Critical Care, 21(3).

Hernandez-Gancedo, C., Pestana, D., Pena, N., Royo, C., Perez-Chrzanowska, H., \& Criado, A. (2006). Monitoring sedation in critically ill patients: bispectral index, Ramsay and observer scales. European journal of anaesthesiology, 23(08), 649-653.

Ismaeil, M. F., El-Shahat, H. M., El-Gammal, M. S., \& Abbas, A. M. (2014). Unplanned versus planned extubation in respiratory intensive care unit, predictors of outcome. Egyptian Journal of Chest Diseases and Tuberculosis,63(1), 219-231.

Jakob, S. M., Lubszky, S., Friolet, R., Rothen, H. U., Kolarova, A., \& Takala, J. (2007). Sedation and weaning from mechanical ventilation: effects of process optimization outside a clinical trial. Journal of critical care, 22(3).

Lutz, A., \& Spies, C. (2011). ICU delirium: Consequences for management of analgesia and sedation in the critically ill. Anasthesiologie, Intensiomedizin, Notfallmedizin, Schmerztherapie: AINS, 46(9), 568-572.

Martin, J., Heymann, A., Bäsell, K., Baron, R., Biniek, R., Bürkle, H., ... \& Spies, C. (2010). Evidence and consensus-based German guidelines for the management of analgesia, sedation and delirium in intensive careshort version. GMS German Medical Science, 8.

Mendes, C. L., Vasconcelos, L. C. S., Tavares, J. S., Fontan, S. B., Ferreira, D. C., Diniz, L. A. C., ... \& Silva, S. L. D. D. (2008). Ramsay 
and Richmond's scores are equivalent to assessment sedation level on critical patients. Revista Brasileira de terapia intensiva, 20(4), 344-348.

Prottengeier, J., Moritz, A., Heinrich, S., Gall, C., \& Schmidt, J. (2014). Sedation assessment in a mobile intensive care unit: a prospective pilot-study on the relation of clinical sedation scales and the bispectral index. Critical Care, 18(6), 615.

Ramsay, M. A., Nasraway Jr, T. A., Wu, E. C., Kelleher, R. M., Yasuda, C. M., Donnelly, A. M. (2002). How reliable is the bispectral index in critically ill patients? A prospective comparative single-blinded observer study. Critical Care Medicine, 30(7):1483-7.

Randen, I., \& Bjørk, I. T. (2010). Sedation practice in three Norwegian ICUs: a survey of intensive care nurses' perceptions of personal and unit practice.Intensive and Critical Care Nursing, 26(5), 270-277.

Rassin, M., Sruyah, R., Kahalon, A., Naveh, R., Nicar, I., \& Silner, D. (2007). "Between the Fixed and the Changing": Examining and Comparing Reliability and Validity of 3 Sedation-Agitation

Scales. Dimensions of Critical Care Nursing, 26(2), 76-82.

Seidabady, M., Mofrad, M. N., \& Zayeri, F. (2014). A Study of Correlation between Ramsay "Sedation Level" Scale and Richmond "Agitation-Sedation"Scale and Physiological Parameters to Determine the Need for Sedation in Patients Undergoing Mechanical Ventilation. Biosciences Biotechnology Research Asia. Vol. 11(2).

Sessler, C. N., \& Wilhelm, W. (2008). Analgesia and sedation in the intensive care unit: an overview of the issues. Crit Care, 12(Suppl 3), S1.

Sessler, C. N., Gosnell, M. S., Grap, M. J., Brophy, G. M., O'Neal, P. V., Keane, K. A., ... \& Elswick, R. K. (2002). The Richmond Agitation-Sedation Scale: validity and reliability in adult intensive care unit patients. American journal of respiratory and critical care medicine, 166(10).

Shehabi, Y., Bellomo, R., Reade, M. C., Bailey, M., Bass, F., Howe, B., ... \& Weisbrodt, L. (2012). Early intensive care sedation predicts longterm mortality in ventilated critically ill patients. American journal of respiratory and critical care medicine, 186(8), 724-731.

Stefan, M. S., Shieh, M. S., Pekow, P. S., Rothberg, M. B., Steingrub, J. S., Lagu, T., \& Lindenauer, P. K. (2013). Epidemiology and outcomes of acute respiratory failure in the United States, 2001 to 2009: A national survey.Journal of Hospital Medicine, 8(2), 7682.

Tadrisi, S. D., Madani, S. J., Farmand, F., Ebadi, A., Karimi Zarchi, A. A., Saghafinia, M., ... \& Motahedian, T. E. (2009). Richmond Agitation-Sedation Scale Validity And Reliability In Intensive Care Unit Adult Patients; Persian Version. Iranian Journal of Critical Care Nursing (IJCCN).

Taylor, F. (2006). A comparative study examining the decision-making processes of medical and nursing staff in weaning patients from mechanical ventilation. Intensive and Critical Care Nursing 22, 253-63.

The Joint Commission. (2012). Safe use of opioids in hospitals. Sentinel Event Alert, Issue 49.

Triltsch, A. E., Nestmann, G., Orawa, H., Moshirzadeh, M., Sander, M., Grobe, J., ... \& Spies, C. D. (2005). Correction: Bispectral index versus COMFORT score to determine the level of sedation in paediatric intensive care unit patients: a prospective study. Critical Care, 9(5), 426.

Walker, N \& Gillen, P. (2006). Investigating nurses' perceptions of their role in managing sedation in intensive care: an exploratory study. Intensive Crit Care Nurs ;22:338-45.

Walsh, T. S., Ramsay, P., \& Kinnunen, R. (2008). Monitoring sedation in the intensive care unit: Can "black boxes" help us? Intensive Care Medicine, 30(8):1511-3

Wunsch, H., Linde-Zwirble, W. T., Angus, D. C., Hartman, M. E., Milbrandt, E. B., \& Kahn, J. M. (2010). The epidemiology of mechanical ventilation use in the United States. Critical care medicine, 38(10). 